\title{
Cadmium and Lead Retention in Fresh and Rotten Red Meat
}

\author{
Mariangela V. Lopes, ${ }^{*, a, b}$ Mauro Korn, ${ }^{a}$ Madson de Godoi Pereira, ${ }^{a}$ Eliziane Pedra de Santana, ${ }^{a}$ \\ Fabio Santos de Oliveira ${ }^{b}$ and Maria das Graças A. Korn ${ }^{b}$
}

\author{
${ }^{a}$ Departamento de Ciências Exatas e da Terra and Departamento de Ciências da Vida, Universidade do \\ Estado da Bahia, R. Silveira Martins, 2555, 41195-001 Salvador-BA, Brazil \\ ${ }^{b}$ Instituto de Química, Universidade Federal da Bahia, Campus Universitário de Ondina, \\ 40170-290 Salvador-BA, Brazil
}

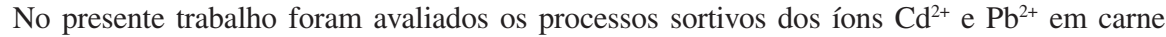
bovina em pH 6. Uma válvula de seleção de 8 canais foi utilizada para a mecanização do preparo das amostras e as concentrações de cádmio e chumbo foram determinadas por ICPOES. Observou-se alta retenção $(>80 \%, \mathrm{~m} / \mathrm{m})$ dos íons $\mathrm{Cd}^{2+}$ e $\mathrm{Pb}^{2+}$ em carne fresca ou putrefata, indicando os riscos associados ao consumo de carne inadequadamente abatida, manipulada, estocada e/ou comercializada. Ácido acético a $1 \%$ (v/v) disponibilizou $70 \%$ do cádmio inicialmente adsorvido nas amostras de carne, revelando que práticas culinárias podem influenciar na sorção dos contaminantes.
\end{abstract}

The metal sorption capacity in fresh and rotten red meat was evaluated for $\mathrm{Cd}^{2+}$ and $\mathrm{Pb}^{2+}$ ions at $\mathrm{pH} 6$ and the process involved in the studied metal retention was discussed. For the experimental set, an eight channels multi-port selection valve was employed to mechanise the sample preparation. The cadmium and lead concentrations were determined by ICP-OES. A high retention $(>80 \%, \mathrm{~m} / \mathrm{m})$ of $\mathrm{Cd}^{2+}$ and $\mathrm{Pb}^{2+}$ ions, in fresh and rotten bovine muscle was found, indicating the potential contamination risks related to the consumption of meat submitted to inappropriate conditions of abattoir, handling, storage and commercialisation. Seventy per cent of the cadmium was released with the immersion of meat in acetic acid at $1 \%(\mathrm{v} / \mathrm{v})$, revealing that cookery practices may act on contaminant sorptive processes in meat structure.

Keywords: cadmium retention, lead retention, meat, metal sorption, meat contaminants

\section{Introduction}

Meat is an important source of nutrients with notable biological value, including chromium, cobalt, copper, iron, magnesium, nickel, selenium, zinc, phosphorus, vitamins, amino acids and proteins. ${ }^{1}$ Due to its nutritional properties, meat is extensively consumed in different countries ${ }^{2}$ and, only in Brazil, the consumption was estimated at $38 \mathrm{~kg}$ per inhabitant ${ }^{3}$ in 2004. However, some animals are slaughtered in inadequate sanitary conditions at the village level in rural areas. Often animals are killed and the meat sold in those villages during periodic local markets, which are held weekly. As occurs in many underdeveloped countries, it is relatively common in villages to slaughter and distribute meat on a cost-sharing basis among several families. Animals are killed, flayed and cut near the site

*e-mail: mlopes@uneb.br where they are consumed. This is done on the ground, usually close to a water stream where meat and entrails can be washed. ${ }^{4}$ Nevertheless, in urban areas, animal slaughter is usually done under adequate conditions in inspected abattoirs.

High consumption of meat and its derivative products can be also unsafe when inappropriate storage/commercialisation practices are adopted. The literature reports some problems related to the growth of pathogenic microorganisms, lipid oxidation and migration of compounds from the packing material to the product. ${ }^{2}$ Heavy metal retention in bovine muscles can also provoke hurtful effects to meat quality. This is possible to happen in villages without sanitary vigilance and water treatment, so that river water can be used for removing blood residues of the slaughtered animals.

Among the possible metallic water contaminant, cadmium and lead need special care due to their remarkable toxicity. ${ }^{5,6}$ The hazardous effects of both metals 
to human health include diseases, such as anaemia, osteomalacia, renal collapse, infertility, cancer and neurological disorders. ${ }^{7-13}$

In the present work, the red meat retention capacity of $\mathrm{Cd}^{2+}$ and $\mathrm{Pb}^{2+}$ ions was evaluated. In this sense, bovine muscle samples were maintained in static contact with $\mathrm{Cd}^{2+}$ and $\mathrm{Pb}^{2+}$ ions in different experimental conditions in order to observe possible contaminations of meat consumed in underdeveloped villages.

\section{Experimental}

\section{Apparatus}

A Fisons model ARL 3410 inductively coupled plasma optical emission spectrometer (ICP-OES) with radial view was used for the determination of cadmium and lead. High purity deionised water $(18.2 \mathrm{M} \Omega \mathrm{cm})$ was obtained from a Barnstead, model EASYpure RF water purification unit, while a Digimed model DM 21 pHmeter was employed for all $\mathrm{pH}$ measurements. For meat sterilisation and grieving, a sterilizer Fabbe model 103 and a domestic food processor equipped with stainless knifes were employed, respectively. An 8 channel-multiposition selection valve Cheminert ${ }^{\mathrm{TM}}$ 25C-3188EMH (Valco Instruments) was used. A microcomputer was employed to control meat sample exposure in some retention assays. A peristaltic pump Gilson Minipuls 3 was employed for fluid propulsion. The system used for retention experiments can be seen in Figure 1.

\section{Reagents, solutions and samples}

All solutions were prepared from analytical reagentgrade (Merck or similar). Glassware was maintained in a $10 \%$ (v/v) $\mathrm{HNO}_{3}$ solution for $24 \mathrm{~h}$ and subsequent cleaning with ultra-pure water. Reference solutions containing cadmium and/or lead (1.0-10 $\left.\mathrm{mg} \mathrm{L}^{-1}\right)$ were obtained from dilutions of $1000 \mathrm{mg} \mathrm{L}^{-1}$ cadmium and lead stock solutions (Tec-Lab). Single or synthetic mixed solutions of cadmium and lead at $10 \mathrm{mg} \mathrm{L}^{-1}$, used for the retention studies, were obtained by diluting the stock solutions with tap water (at pH 6.0) to simulate the possible aqueous matrices used in real cleaning practices. The solutions' $\mathrm{pH}$ were adjusted to 6.0 with a $0.1 \mathrm{~mol} \mathrm{~L}^{-1} \mathrm{NaOH}$ solution.

Fresh bovine muscle samples were collected in Salvador local urban market Bahia State, Brazil. Rotten meat samples were obtained after room temperature $\left(25-27^{\circ} \mathrm{C}\right)$ storage for $12 \mathrm{~h}$ of the fresh meat samples. The meat samples used in retention experiments were previously inspected by the Brazilian Sanitary Service. In order to evaluate the effects associated to the increase of surface area and microbial activity, some samples of meat were sterilised during 30 min at $124{ }^{\circ} \mathrm{C}$. The metal retention in fresh and rotten meat grieved samples was also evaluated.

Automation of the retention experiments by using multiposition valve

For this purpose, six channels (numbers 3-8) of the multiposition selection valve were connected to individual flasks (Figure 1) containing $1 \mathrm{~g}$ of fresh or rotten pieced meat. In the next step, $2.5 \mathrm{~mL}$ of the mixed solution were aspirated from channel 2 of the multiposition selection valve to the holding coil and pumped to the samples flaks. In this condition, an unique portion of meat sample was maintained in contact with the mixed solution for 1, 2, 4 and $8 \mathrm{~h}$. During the $8 \mathrm{~h}$ period, part of the experiments was conduced by changing the aliquots of the mixed solution in intervals of 1 $\mathrm{h}$, while another part was carried out fixing the same aliquot volume during the established period $(8 \mathrm{~h})$. These experiments were performed for evaluating the retention kinetic profiles.

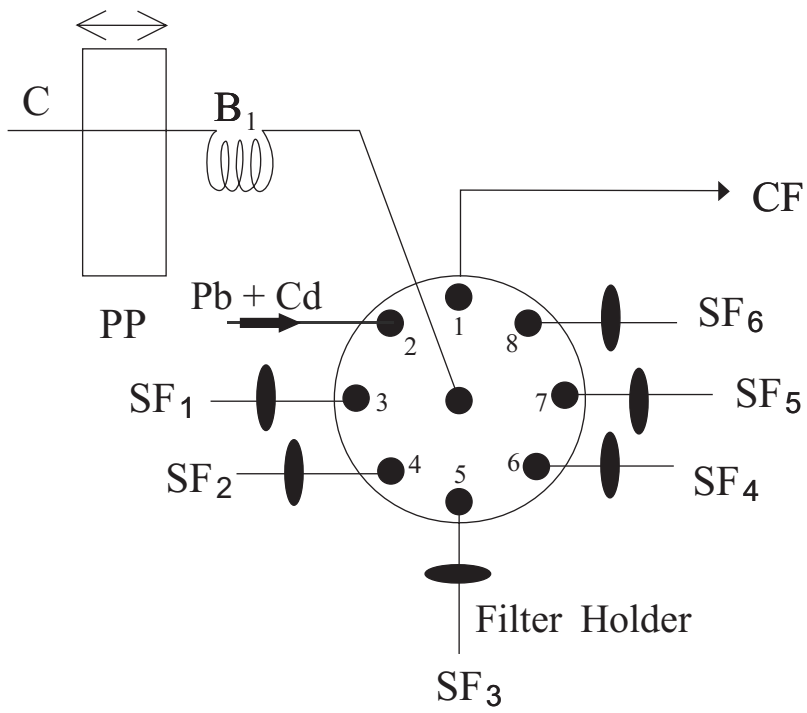

Figure 1. Automated experimental setup: $\mathrm{SF}_{1}$ to $\mathrm{SF}_{3}$ (sample flasks) containing metal solution in contact with meat submitted to renewed aliquot volume after $1 \mathrm{~h}$, during $8 \mathrm{~h} ; \mathrm{SF}_{4}$ to $\mathrm{SF}_{6}$ containing metal solution in contact with $1 \mathrm{~g}$ of meat, during $8 \mathrm{~h}$; PP (Peristaltic Pump); C (Carrierdeionised water); $\mathrm{B}_{1}$ (Holding Coil) and $\mathrm{CF}$ (Collection Flask).

After exposure period, the supernatants were aspirated into the holding coil and pumped out towards the collection flask. The supernatants were digested with 2 $\mathrm{mL}$ of $14 \mathrm{~mol} \mathrm{~L}^{-1} \mathrm{HNO}_{3}$ and $1 \mathrm{~mL}$ of $30 \%(\mathrm{~m} / \mathrm{v}) \mathrm{H}_{2} \mathrm{O}_{2}$ at $70{ }^{\circ} \mathrm{C}$. Then, evaporated to near dryness in order to eliminate the organic materials. The digestion procedure was repeated three times and the resultant solutions filtered. The extracts were diluted with deionised water to $5 \mathrm{~mL}$. Cadmium and lead concentrations were measured at emission lines of 214.439 and $220.353 \mathrm{~nm}$, respectively. 


\section{Retention experiments in batch mode}

In this study, portions of $1 \mathrm{~g}$ of sterilised or raw meat samples were exposed to $2.5 \mathrm{~mL}$ of $10 \mathrm{mg} \mathrm{L}^{-1} \mathrm{Cd}$ or $\mathrm{Pb}$ solutions for 2 or $4 \mathrm{~h}$. After the filtration step, the samples were digested to eliminate organic material as discussed above. For each combination between sterilised and raw bovine muscle, the grieved (presenting higher surface area) and pieced samples were evaluated in order to investigate how the surface area acts on the retentions of cadmium and lead.

Possible metal displacement effects were evaluated by immersing $1 \mathrm{~g}$ of the grieved or pieced fresh meat (not submitted to sterilisation) into solutions containing $10 \mathrm{mg}$ $\mathrm{L}^{-1} \mathrm{Cd}$ or $\mathrm{Pb}$ for $8 \mathrm{~h}$. Following, meat samples initially immersed in cadmium were dipped into $2.5 \mathrm{~mL}$ of $10 \mathrm{mg}$ $\mathrm{L}^{-1}$ lead solutions for $1 \mathrm{~h}$ and vice-versa.

In order to obtain data on the sorption mechanisms after microrganism death as well as on the effect of the increase of the surface area, $1 \mathrm{~g}$ of a bovine muscle sample acquired just before these set of experiments was grieved or sterilised for subsequent immersion into $2.5 \mathrm{~mL}$ of 10 $\mathrm{mg} \mathrm{L} \mathrm{L}^{-1} \mathrm{Cd}$ or $\mathrm{Pb}$ solutions for $2 \mathrm{~h}$.

Acetic acid effect in $\mathrm{Cd}^{2+}$ and $\mathrm{Pb}^{2+}$ ions retention/ leaching was also evaluated. $\mathrm{Cd}^{2+}$ and $\mathrm{Pb}^{2+}$ ions leaching effect was evaluated by adding $2.5 \mathrm{~mL}$ of the mixed solution $\left(10 \mathrm{mg} \mathrm{L}^{-1}\right)$ to $1 \mathrm{~g}$ of the pieced fresh meat. After $4 \mathrm{~h}$, meat was washed with deionised water and cooked using acetic acid solutions of 1.0, 0.5, 0.25, 0.1 and $0 \%$ (v/v). The effect of the acetic acid in $\mathrm{Cd}^{2+}$ and $\mathrm{Pb}^{2+}$ ions retention was evaluated by cooking the pieced fresh meat for $5 \mathrm{~min}$ in acetic acid solutions (1.0, 0.5, 0.25, 0.1 and $0.0 \%, \mathrm{v} / \mathrm{v})$ and washing with deionised water, followed by metal contamination with $2.5 \mathrm{~mL}$ of the mixed solution.

In order to avoid the introduction of solutions containing high organic concentrations in the ICP-OES equipment, the organic species in the supernatants were digested as described earlier. In this case, the multi-position valve was not used in order to prevent clogging problems associated with the use of sterilised or grieved meat samples.

\section{Results and Discussion}

Figures 2 and 3 show the retention profiles of cadmium and lead in pieced samples of fresh and rotten meat, respectively. In this experiment, aliquots of the mixed solution were changed each $1 \mathrm{~h}$ during $8 \mathrm{~h}$, as previously described. Takink into account a same piece of fresh meat, a continuous increase in the lead retention was found with the addition of $2.5 \mathrm{~mL}$ aliquots (Figure 2). For cadmium, a diverse behaviour was obtained due to the different sorption mechanisms for $\mathrm{Cd}^{2+}$ and $\mathrm{Pb}^{2+}$ ions. The presence of $\mathrm{Pb}^{2}$ ions inhibits the cadmium retention. For rotten meat (Figure 3), a significant decrease with the time of contact was only observed for cadmium.

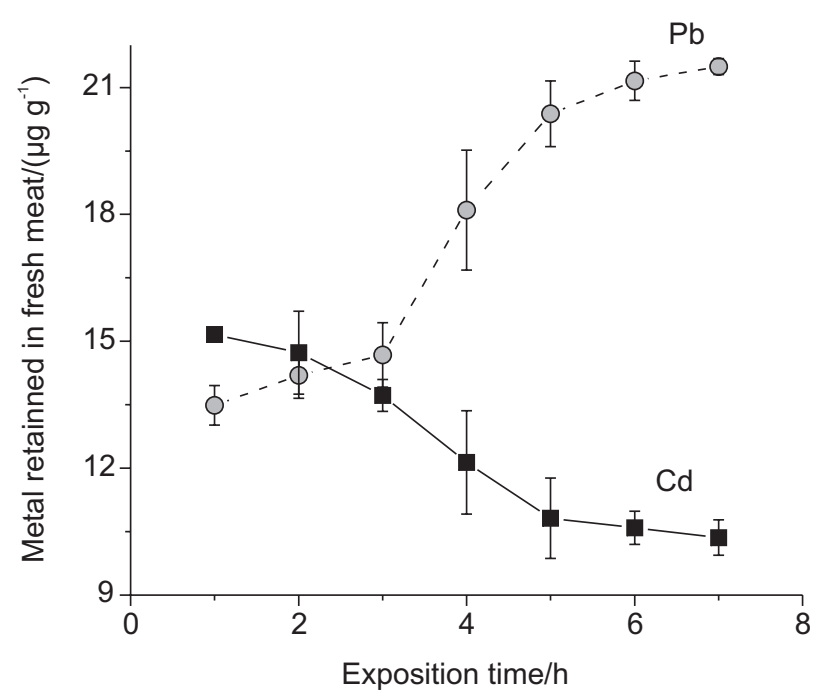

Figure 2. Cadmium and lead retention profiles in fresh meat by changing cadmium and lead synthetic mixed solution.

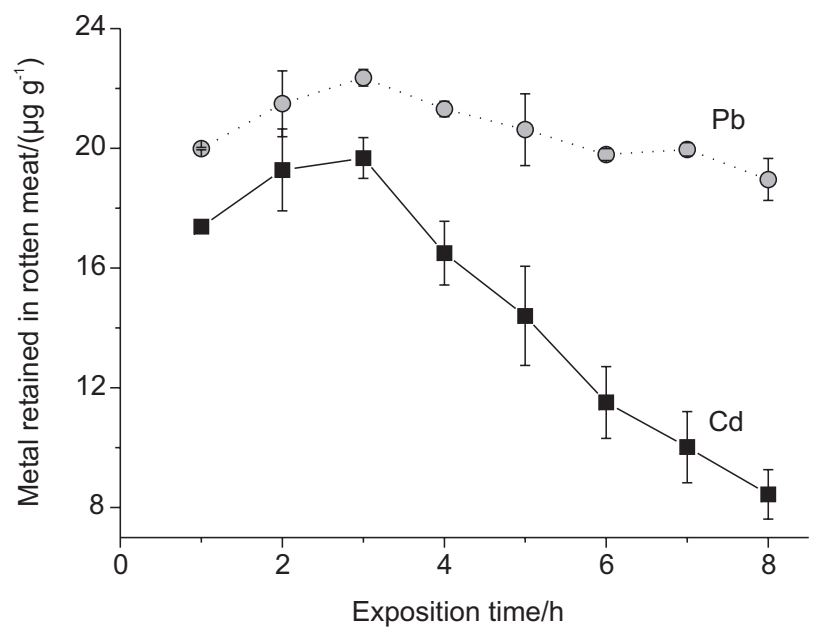

Figure 3. Cadmium and lead retention profiles in rotten meat by changing cadmium and lead synthetic mixed solution.

Based on the behaviour of both metals in different matrices, such as soils, sediments and resins, ${ }^{14}$ as well as, on the magnitude of the constants related to complex stability and precipitate formation, ${ }^{15}$ the lead adsorption in meat can be attributed to oxygen, sulphur and/or nitrogen from carbonyl, hydroxyl, amine and sulfidrilic groups derived from oxidative process and the cleavage of protein bonds during meat putrefaction. Amine groups of protein are the main groups in cadmium sorption.

The sorption profiles of $\mathrm{Cd}^{2+}$ and $\mathrm{Pb}^{2+}$ ions in fresh and in rotten meat samples (Figures 4, 5) for interval time from 1 to $8 \mathrm{~h}$ were evaluated. Saturation condition was attained after $1 \mathrm{~h}$ for both ions in rotten bovine muscle (mainly for lead) 
and after $4 \mathrm{~h}$ for fresh meat. The saturation observed in the Figures 4 and 5 cannot be compared with those showed in Figures 2 and 3, where aliquots of the $10 \mathrm{mg} \mathrm{L}^{-1} \mathrm{Cd}+\mathrm{Pb}$ solution were changed at each $1 \mathrm{~h}$.

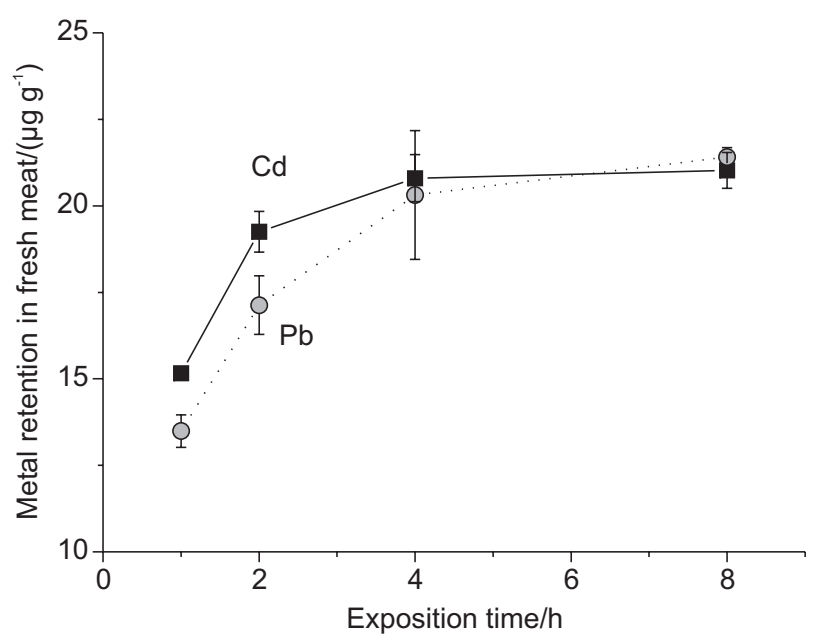

Figure 4. Cadmium and lead retention profiles in fresh meat without change of cadmium and lead synthetic mixed solution.

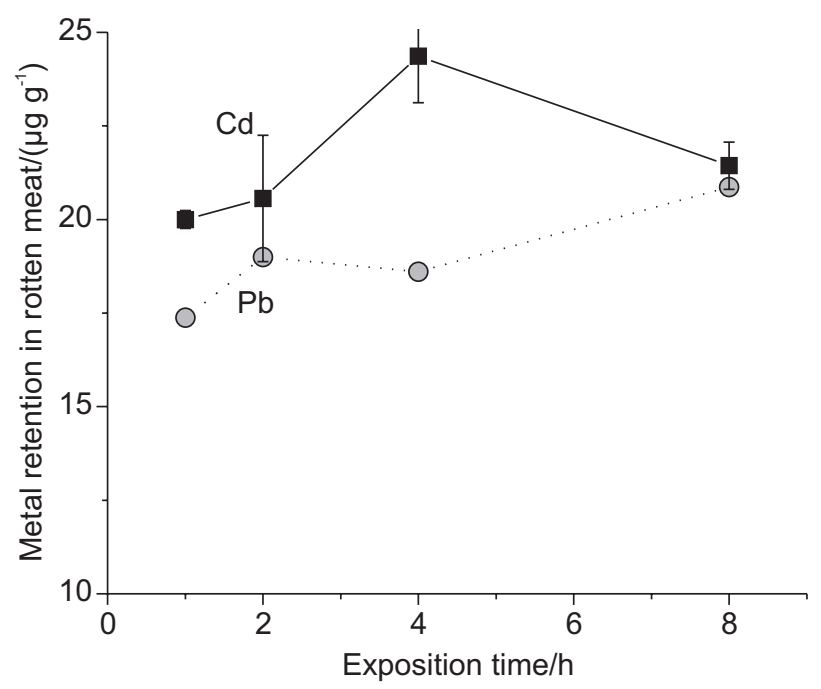

Figure 5. Cadmium and lead retention profiles in rotten meat without change of cadmium and lead synthetic mixed solution.

The cadmium retention in rotten meat (Figure 5) was greater than in fresh samples (Figure 4) due to the increase of chelating amine groups in the putrefied meat structure.
However, the effect of the microbial population in metal sorption cannot be explained only by these experiments, thus requiring an analysis of the data related to the sterilisation experiments as showed in Table 1.

Since microbial population of meat samples is killed with sterilisation, the metal sorption occurs in absence of other source of sulfidrilic groups. The strong interaction among metallic ions and $-\mathrm{S}-\mathrm{H}$ groups justifies the small variation $(<7 \%)$ in $\mathrm{Pb}^{2+}$ and $\mathrm{Cd}^{2+}$ ions sorptions in fresh meat after the thermal treatment (Table 1), since sterilisation prevents thiogroups generation. Another interesting characteristic of $\mathrm{Cd}^{2+}$ ion sorption in meat sample comprises its independence related to the increase of the meat surface area after sterilisation, as can be evaluated by comparing the sorption experiments for grieved and pieced samples (Table 1). In contrast, the surface area effect in $\mathrm{Pb}^{2+}$ ion sorption resulted in differences higher than $10 \%$, in mass, by comparing the retention in the pieced and grieved meat samples as can be seen in Table 1. In spite of the higher surface area of grieved meat samples the retention of $\mathrm{Pb}^{2+}$ in grieved samples (presenting a more pronounced surface area) was always lower than those observed for the pieced samples. A possible reason for this fact is the higher content of fatty in the grieved meat as compared with the pieced meat.

Cadmium retention was slightly lower in the sterilised samples, thus indicating possible differentiation related to mechanisms involved in the lead and cadmium sorptions. In order to investigate this behaviour, a study was designed to evaluate metallic ion displacements. After immersion of the fresh meat samples for $8 \mathrm{~h}$ in cadmium or lead solution, the supernatants were collected and the pieced meat samples were immersed into other metal solution containing lead or cadmium for $1 \mathrm{~h}$. Metallic ions displacements were not significant $(<10 \%)$, suggesting the existence of different or preferential sites for the retention $\mathrm{Cd}^{2+}$ and $\mathrm{Pb}^{2+}$ ions.

The different simulations of cookery practices with acetic acid elucidated two aspects: $(i)$ how cooking acts on the release of cadmium and lead ions from contaminated meat (Table 2); and (ii) how cooked meat in acidic medium retains $\mathrm{Cd}^{2+}$ and $\mathrm{Pb}^{2+}$ ions from aqueous solutions

Table 1. Effect of the sterilisation process in cadmium and lead retention (in $\% \mathrm{~m} / \mathrm{m}$ ) in fresh and rotten pieced and grieved meat samples for an exposition time of $2 \mathrm{~h}(\mathrm{n}=3)$

\begin{tabular}{|c|c|c|c|c|c|c|c|c|}
\hline \multirow[t]{3}{*}{ Meat } & \multicolumn{4}{|c|}{$\mathrm{Cd}$} & \multicolumn{4}{|c|}{$\mathrm{Pb}$} \\
\hline & \multicolumn{2}{|c|}{ Fresh meat } & \multicolumn{2}{|c|}{ Rotten meat } & \multicolumn{2}{|c|}{ Fresh meat } & \multicolumn{2}{|c|}{ Rotten meat } \\
\hline & $S$ & NS & $\mathrm{S}$ & NS & S & NS & $S$ & NS \\
\hline Grieved & $76 \pm 5$ & $78 \pm 3$ & $74 \pm 5$ & $80 \pm 2$ & $48 \pm 5$ & $41 \pm 1$ & $52 \pm 3$ & $38 \pm 6$ \\
\hline Pieced & $75 \pm 1$ & $81 \pm 2$ & $84 \pm 1$ & $72 \pm 8$ & $55 \pm 4$ & $53 \pm 4$ & $71 \pm 1$ & $72 \pm 8$ \\
\hline
\end{tabular}

S: Sterilised; NS: Not sterilised. 
(Table 3). Although, the first aspect is concerned with meat consumption commercialised under unsafe conditions, the second deals with the use of contaminated waters, with heavy metals in food preparation. Most of the lead was not released from the meat when the acetic acid concentration was increased (Table 2). The efficiency of cadmium extraction was improved with the increase of the acetic acid concentration. Almost $70 \%$ of $\mathrm{Cd}^{2+}$ ions were released when $1 \%(\mathrm{v} / \mathrm{v})$ acetic acid solution was employed. The different behaviours of cadmium and lead extractions were probably associated with the different groups responsible for their retention as already commented.

Table 2. Remaining fraction of cadmium and lead contents $(\%, \mathrm{~m} / \mathrm{m})$ in fresh meat samples contaminated with these metals and cooked with acetic acid solution at various concentrations $(n=3)$

\begin{tabular}{lcccc}
\hline \multirow{2}{*}{$\begin{array}{l}\text { Acetic Acid } \\
\begin{array}{l}\text { Concentration } \\
(\%, \mathrm{v} / \mathrm{v})\end{array}\end{array}$} & Mean & $\mathrm{RSD}$ & Mean & $\mathrm{RSD}$ \\
\cline { 2 - 5 } & & & & \\
\hline 0 & 97.4 & 0.1 & 99.3 & 0.1 \\
0.1 & 95.8 & 0.8 & 79.4 & 5.6 \\
0.25 & 93.4 & 0.2 & 55.8 & 0.3 \\
0.5 & 91.8 & 0.8 & 46.3 & 2.0 \\
1.0 & 90.8 & 0.1 & 27.2 & 1.4 \\
\hline
\end{tabular}

Cadmium sorption decreases as the acetic acid concentration increases (Table 3) due to the protonation of the sites involved in the cadmium retention. The cadmium retention was decreased from 91.9 to $12.7 \%$ by increasing the acetic acid concentration up to $1 \%$, contrasting with the lead behaviour. These results reinforce that different groups are involved in the cadmium and lead retentions, since $\mathrm{Cd}^{2+}$ ions complex with amino groups from proteins, $\mathrm{Pb}^{2+}$ ions could be precipitated by thiogroups.

Table 3. Cadmium and lead retained contents $(\%, \mathrm{~m} / \mathrm{m})$ after exposition for $4 \mathrm{~h}$ to single metal ions solutions of the fresh meat samples cooked with acetic acid solutions at various concentrations $(n=3)$

\begin{tabular}{lcccc}
\hline \multirow{2}{*}{$\begin{array}{l}\text { Acetic Acid } \\
\begin{array}{l}\text { Concentration } \\
(\%, \mathrm{v} / \mathrm{v})\end{array}\end{array}$} & Mean & $\mathrm{RSD}$ & Mean & $\mathrm{RSD}$ \\
\cline { 2 - 5 } & & & & \\
\hline 0 & 96.0 & 0.1 & 91.9 & 0.1 \\
0.1 & 89.6 & 0.1 & 42.6 & 0.6 \\
0.25 & 89.0 & 0.2 & 44.9 & 0.5 \\
0.5 & 86.8 & 0.8 & 29.5 & 0.1 \\
1.0 & 87.2 & 0.1 & 12.7 & 1.8 \\
\hline
\end{tabular}

The thematic of this work deals with cadmium and lead sorptions in bovine muscle and, for this reason, it was not performed an environmental monitoring of cadmium and lead natural content in these samples. However, the literature offers some publications related to this subject. In this way, according to Abou-Arab, ${ }^{16}$ cadmium and lead concentrations in bovine muscle collected in Egypt rural areas attained values of $0.010 \pm 0.010 \mathrm{mg} \mathrm{kg}^{-1}$ and $0.061 \pm 0.030$ $\mathrm{mg} \mathrm{kg}{ }^{-1}$, respectively. Unfortunately, it is very difficult to establish any comparison between this data due to the great variety of the factors responsible for the heavy metals presence in meats. From these factors, soil composition, local anthropogenic activities and differences in the animal metabolism should be considered.

\section{Conclusions}

By means of the high-retained masses of both metallic species in fresh and rotten bovine muscles, it was possible to obtain preliminary information about the potential risks associated to the consumption of meat contaminated with $\mathrm{Cd}^{2+}$ and $\mathrm{Pb}^{2+}$ ions. So, it is necessary to establish rigid safety conditions related to abattoir operating procedures, like handling, storage and meat commercialization since more than $20 \mu \mathrm{g}$ of each ion were retained in an $1 \mathrm{~g}$ meat piece after few minutes of contact with simulating contaminated water solution. Based in metal retention results, different sorptive sites for $\mathrm{Cd}^{2+}$ and $\mathrm{Pb}^{2+}$ sorptions were proposed, as well as, based in the importance of meat condition (fresh and rotten) concerning metal accumulation processes.

\section{Acknowledgments}

Authors M.K., M.G.A.K. and M.G.P thank CNPq, while F.S.O. and E.P.S. are grateful to FAPESB for fellowships. M.K., M.G.P., M.V.L. and M.G.A.K. are grateful to N.Q.A. (PRONEX/FAPESB-CNPq) financial support. M.G.P. thanks the financial support from FAPESB (PRODOC).

\section{References}

1. Higgs, J.D.; Trend Food Sci. Technol. 2000, 11, 85.

2. Jiménez-Colmenero, F.; Carballo, J.; Cofrades, S.; Meat Sci. 2001, 59, 5.

3. Instituto FNP. Anualpec 2005. São Paulo: Instituto FNP Consultoria e Comércio, 2005, p. 340.

4. Joshi, D.D.; Maharjan, M.; Johansen, M.V.; Willingham, A.L.; Sharma, M.; Acta Tropica 2003, 87, 119.

5. Robards, K.; Worsfold, P.; Analyst 1991, 116, 549.

6. Deydier, E.; Guilet, R.; Sharrock, P.; J. Haz. Mat. 2003, 101, 55.

7. Mena, C.; Cabrera, C.; Lorenzo, M. L.; Sci. Total Environ. 1996, $181,201$. 
8. Liu, F.; Jan, K.Y.; Free Radic. Bio. Med. 2000, 28, 55.

9. Jonhson, F.M.; Mutation Res. Rev. 1998, 410, 123.

10. Gurer, H.; Ercal, N.; Free Radic. Bio. Med. 2000, 29, 927.

11. Solé, E.; Ballabriga, A.; Dominguez, C.; Sci. Total Environ. 1998, 224, 19.

12. Katsuta, O.; Hiratsuka, H.; Matsumoto, J.; Iwata, H.; Toyota, N.; Tsuchitani, M.; Umemura, T.; Marumo, F.; Toxicol. Appl. Pharmacol. 1994, 126, 58.

13. Benoff, S.; Jacob, A.; Hurley I.R.; Hum. Reprod. 2000, 6, 107.
14. Ganjali, M.R.; Basiripour, F.; Shamsipur M.; Hashemi O.R.; Moghimi A.; Aghabozorg, H.; Int. J. Environ. Anal. Chem. 2003, 83, 997.

15. Harris, D.C.; Quantitative Chemical Analysis, W. H. Freeman: New York, 2003.

16. Abou-Arab, A. A. K.; Food Chem. Toxicol. 2001, 39, 593.

Received: April 4, 2006

Web Release Date: June 19, 2007 